\title{
Prevalence of non-COVID-19 venous thromboembolism during SARS-CoV-2 outbreak: our experience
}

\section{(D)Ana Marija Slišković*, \\ DMislav Puljević, (D)Ana Šutalo, \\ (D)Ante Bosnić, (D) Ljiljana Banfić, (D) Majda Vrkić Kirhmajer}

University of Zagreb School of Medicine, University Hospital Centre Zagreb, Zagreb, Croatia
RECEIVED:

December 5, 2020

ACCEPTED:

December 18, 2020

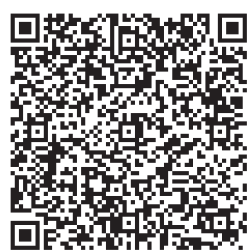

KEYWORDS: venous thromboembolism, non COVID-19 patients, SARS-CoV-2 outbreak. CITATION: Cardiol Croat. 2021;16(1-2):71. | https://doi.org/10.15836/ccar2021.71

*ADDRESS FOR CORRESPONDENCE: Ana Marija Slišković, Klinički bolnički centar Zagreb, Kišpatićeva 12, HR-10000 Zagreb, Croatia. / Phone: +386-99-4089160 / E-mail: sliskovic_anamarija@yahoo.com

ORCID: Ana Marija Slišković, https://orcid.org/0000-0001-6622-7572 • Mislav Puljević, https://orcid.org/0000-0003-1477-2581 Ana Šutalo, https://orcid.org/0000-0002-7644-6362 • Ante Bosnić, https://orcid.org/0000-0003-4019-3874 Ljiljana Banfić, https://orcid.org/0000-0002-4538-8980 • Majda Vrkić Kirhmajer, https://orcid.org/0000-0002-1340-1917

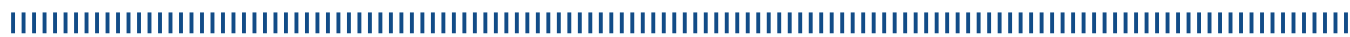

Background: In March 2020 formally declared pandemic of coronavirus disease (COVID-19) caused a global impact on public health. Venous thromboembolism (VTE) encompassing pulmonary embolism (PE) and deep venous thrombosis (DVT) is frequently observed in patients with COVID-19'1, while the pandemic influence on non COVID-19 VTE prevalence remains unknown. Previous meta -analysis supported an association between regular physical activity and lower risk of VTE when compared with a sedentary or less active lifestyle ${ }^{2}$. Aim: to investigate the influence of pandemic circumstances on the prevalence of non COVID-19 patients hospitalized due to VTE.

Patients and Methods: Single centre retrospective analysis of consecutive non COVID-19 patients admitted for VTE was performed. We compared demographic characteristics and diagnostics findings in patients hospitalized for VTE between 1st of March and 31st of October 2019 and non COVID-19 VTE patients hospitalized between the same period in 2020. All patients underwent laboratory tests, venous ultrasonography of the lower limbs and/or CT pulmonary angiography and had negative swab test for SARS-CoV2 at admission. One patient had previously recovered from COVID-19.

Results: During the period of 8 months 70 VTE patients (female $48 \%$, mean age $60.8 \pm 17.2$ years) were admitted in 2019, while 86 non COVID-19 VTE patients (female $50 \%$, mean age $68.5 \pm 16.8$ years) were admitted in 2020. There was no significant difference in prevalence of VTE hospitalization $(4.1 \% \mathrm{vs} 5.4 \%$, $\mathrm{p}=0.106)$, but patients in 2020 were significantly older $(\mathrm{p}=0.002)$. Dividing the VTE cases into isolated PE, isolated DVT and combined DVT+PE we found a significant increase in prevalence of DVT+PE during pandemic (34 vs 36, $p=0.23$; 23 vs $25, p=0.24$ and 13 vs $25, p=0.03$, respectively).

Conclusion: During COVID 19 pandemic we observed significant increase in prevalence of hospitalized non COVID-19 patients with combined DVT+ PE but not with isolated PE or isolated DVT. Possible explanation could be a less active lifestyle due to pandemic social restriction recommendation and delaying treatment for initial DVT.

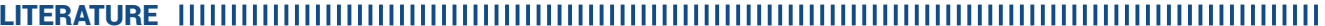

1. Bikdeli B, Madhavan MV, Jimenez D, Chuich T, Dreyfus I, Driggin E, et al; Global COVID-19 Thrombosis Collaborative Group, Endorsed by the ISTH, NATF ESVM, and the IUA, Supported by the ESC Working Group on Pulmonary Circulation and Right Ventricular Function. COVID-19 and Thrombotic or Thromboembolic Disease: Implications for Prevention, Antithrombotic Therapy, and Follow-Up: JACC State-of-the-Art Review. J Am Coll Cardiol. 2020 Jun 16;75(23):2950-2973. https://doi.org/10.1016/j.jacc.2020.04.031

2. Kunutsor SK, Mäkikallio TH, Seidu S, de Araújo CGS, Dey RS, Blom AW, Laukkanen JA. Physical activity and risk of venous thromboembolism: systematic review and meta-analysis of prospective cohort studies. Eur J Epidemiol. 2020 May;35(5):431-442. https://doi.org/10.1007/s10654-019-00579-2 